\title{
Real earnings management and borrowing costs: The moderating effect of the directors' and officers' liability insurance
}

\author{
Jui-I Chang ${ }^{1}$, Chen-Ying Lee ${ }^{2}$ and Geng-Yu Lin ${ }^{3}$
}

\begin{abstract}
The purpose of this paper is to investigate the effects of real earnings management on firm borrowing cost of public-listed in Taiwanese manufacturing industry during 2010 to 2017, and also examines the moderating effect of the directors' and officers' liability insurance (D\&O insurance) on real earnings management and borrowing costs. The empirical results show that borrowing cost is positively related to real earning management but negatively related to $\mathrm{D} \& \mathrm{O}$ insurance purchase. Therefore, the firms with D\&O insurance than those without have lower borrowing costs, but the higher the D\&O insurance amount, the higher the borrowing costs. Furthermore, D\&O insurance has a moderating effect between the real earnings management and borrowing costs. Our findings suggest the relationship between $\mathrm{D} \& \mathrm{O}$ insurance and real earning management, which through the $\mathrm{D} \& \mathrm{O}$ insurance purchasing decision to impact on corporate borrowing costs.
\end{abstract}

JEL classification numbers: G22, G32, M41.

Keywords: Real earnings management, Directors' and officers' liability insurance, Borrowing costs, Moderating effect.

${ }^{1}$ Department of Insurance and Finance, National Taichung University of Science and Technology, Taiwan.

${ }^{2}$ (Corresponding author) Department of Risk Management and Insurance, Shih Chien University, Taiwan.

${ }^{3}$ Master's degree, Department of Insurance and Finance, National Taichung University of Science and Technology, Taiwan.

Article Info: Received: June 18, 2021. Revised: July 11, 2021.

Published online: July 16, 2021. 


\section{Introduction}

When a company requires funding for its operations, it must obtain financing through a corporate financing party. Financing can be divided into two types: debt financing and equity financing. The cost of equity financing involves a large number of factors. However, the Taiwan Economic Journal (TEJ) reports that the average debt-to-equity ratio of Taiwanese listed companies is 1.47 , which suggests that Taiwanese enterprises use debt financing as the main source of funds. The cost of the debt financing, which is divided into direct and indirect financing, is tax deductible. Direct financing refers to when an enterprise issues corporate bonds to investors. Houston and James (1996) indicate that corporate bondholders are more dispersed, and if there is an issue within the enterprise, the debt contract needs to be changed. In this situation, companies are less likely to obtain commitment from all bondholders to make the necessary changes. Indirect financing is for enterprise to borrow from financial institutions. Park (2000) argues that financial institutions have more channels to obtain relevant information about enterprises' performance than general investors do, leading to advantages in terms of reviewing and supervision them, and financial institutions can punish enterprise by re-negotiate or canceling contracts when they discover the actual situation within the enterprise. Watt and Zinnerman (1990) investigated the motivation for companies to manage earnings and proposed the debt /equity hypothesis, which maintains that in order to avoid higher borrowing costs, corporate managers may change their financial statements to reflect an increase in surplus or a reduction in the debt ratio. Trueman and Titman (1988) found that companies obtain funding at a lower cost in order to reduce risk, or use earnings management to obtain better trading conditions. Cohen et al. (2008) found that the proportion of companies using real earnings management after the Sarbanes-Oxley Act was passed, has been increasing annually, while the proportion of those using accrued basic earnings management has been decreasing. Previous studies opine that directors' and officers' liability insurance (D\&O insurance) can help reduce the risk of litigation. For example, Bhagat (1987) demonstrates that $\mathrm{D} \& \mathrm{O}$ insurance can effectively reduce litigation losses and increase shareholder wealth. In 2003, the revised code of practice relating to the corporate governance of listed companies recommended that companies should purchase D\&O insurance for directors and key staff in Taiwan. In 2008, Taiwan was stipulated that listed companies must publicly disclose information regarding their D\&O insurance, and in 2018, enterprises applying to be listed on the stock exchange were required to purchase D\&O insurance. Tsai et al. (2017) used Taiwanese companies as a sample to explore the impact of $\mathrm{D} \& \mathrm{O}$ insurance on the interest rate of interest-bearing liabilities. The results show reveal that there is a negative correlation between $\mathrm{D} \& \mathrm{O}$ insurance coverage and the cost of debt. Using a sample of Canadian companies, Lin et al. (2013) found that a higher level of D\&O insurance coverage has a positive relationship with bond yield and loan spread. Previous literature finds that D\&O insurance has different effects on the debt cost of enterprises in different countries. Therefore, this study further explores the effect 
of $\mathrm{D} \& \mathrm{O}$ insurance on enterprises seeking to borrow from financial institutions. However, Tang et al. (2014) and Yang et al. (2016) have shown that enterprises that purchase D\&O insurance have a larger profit margin than those that do not purchase D\&O insurance; the higher the insurance amount, the greater the margin of earnings management. Therefore, this study further explores the impact of earnings management on enterprises' borrowing costs and whether D\&O insurance has a moderating effect.

The contribution of this paper is the first study in Taiwan context that use real earnings management explore the impact of companies on the borrowing cost from financial institutions to fill in the financial literature. Second, investigates the relationship between $\mathrm{D} \& \mathrm{O}$ insurance and real earning management, which we examine through the $\mathrm{D} \& \mathrm{O}$ insurance purchasing decision and further explore $\mathrm{D} \& \mathrm{O}$ insurance of impact on corporate borrowing costs. Finally, we also contribute to the growing literature on the moderating effects of $\mathrm{D} \& \mathrm{O}$ insurance between real earning management and borrowing cost.

The remainder of the paper is organized as follows. The following section locates this research within the literature on real earning management, D\&O insurance and borrowing cost. The third section explains the research methodology and variables development. Results and discussion are resented in fourth section, followed by concluding remarks in fifth section.

\section{Related Literature and Research Hypotheses}

\subsection{Real earnings management}

Healy and Wahlen (1999) suggest that earnings management occurs when managers use their discretion in financial reporting and in structuring transactions to alter financial reports and mislead some stakeholders about the underlying economic performance of the company, or to influence contractual outcomes that depend on reported accounting numbers. Earnings management is defined as a 'purposeful intervention in the external financial reporting process, with the intent of obtaining some private gain' (Schipper 1989). Roychowdhury (2006) argues that earnings management is mainly in the form of sales manipulation (e. g. easing restrictions on the conditions of sale and credit conditions, increasing sales and discounts, etc.), production control (such as using the scale effect of mass production to reduce the unit product cost), and the control of discretionary expenditure (such as reducing the costs related to research and development, advertising, and maintenance, etc.). Earnings management is achieved through accruals-based and real earnings management activities. The former refers to manipulation through accounting methods, and the latter is manipulation of real activities, including sales, production cost, and discretionary expenses (Gao and Gas, 2016). Previously, scholars believed that the board of directors and managers is relevant to the use of earnings management. For example, Peasnell et al. (2005) examine whether the incidence of earnings management in UK companies depends on board supervision. The study found that the ratio of external board numbers and the accruals used by managers 
to increase the company's income are negatively significantly correlated. Gunny (2010) indicates that corporate managers use real earnings management to achieve performance goals, which may result in lower debt costs, maximization of company stock prices, compliance with corporate stakeholders' expectations, and reduction of litigation risks. Recently, Deng and Ong (2018) find Real Estate Investment Trusts (REITs) with higher liquidity risk are more likely to manipulate earnings prior to equity offerings and uninformed trading is higher following real earnings management.

\subsection{Directors' and officers' liability insurance}

The fundamental idea of $\mathrm{D} \& \mathrm{O}$ insurance is to provide liability protection to boards of directors and executive officers against accusations of wrongful acts in their capacity. Holderness (1990) suggests that D\&O insurance has an important governance role in publicly owned companies, and serves to monitor directors and officers. Lee and Tang (2019) also indicate D\&O insurance will enhance the effectiveness of corporate governance, and prevent the management from engaging in tax avoidance activities. The other view is that $\mathrm{D} \& \mathrm{O}$ insurance provisions create essential layers of protection for a company's directors and officers and thereby lessen the effectiveness of litigation as a monitoring tool (Chung and Wynn 2008; Wynn 2008). However, Gutierrez (2003) argued that D\&O insurance will reduce directors' and management's degree of caution in decision-making matters, and thus increase the risk of litigation claims. Jia and Tang (2018) find a negative relationship between D\&O insurance and personal board meeting attendance by independent directors, and that such insurance encourages independent directors to behave less responsibly. In general, D\&O insurance reduces the effectiveness of independent directors in corporate governance. Liao et al. (2017) suggested that D\&O insurance has a positive effect on earnings management and stability, which can reduce the extent of enterprises' earnings management, indicating the D\&O insurance has a supervisory effect. By contrast, Chung and Wynn (2008) and Yang et al. (2016) found that $\mathrm{D} \& \mathrm{O}$ insurance has a negative effect on earnings management, which will lead to the adoption of corporate management, resulting in increase corporate risk. Recently, Yang et al. (2016) demonstrate that purchasers of $\mathrm{D} \& \mathrm{O}$ insurance are more likely to engage in real earnings management than nonpurchasers are. Furthermore, family-owned firms with D\&O liability insurance are more likely to engage in real earnings management activities than non-familyowned firms are.

\subsection{Borrowing costs}

Sengupta (1998) examined the relationship between the quality of the company's disclosure and the cost of borrowing. Companies with higher quality were found to be able to obtain lower effective interest rates when issuing debts. Francis et al. (2002) finds that firms with lower quality earnings have higher costs of capital, as evidenced by lower debt ratings and larger realized costs of debt. The results reveal 
that firms with the best earnings quality enjoy discounts of 80-160 basis points in their costs of debt and 150-300 basis points in their costs of equity relative to firms with the poorest earnings quality. Liu et al. (2010) find significant incomeincreasing earnings management prior to bond offerings. After controlling for various bond issuer and issue characteristics, they also find that firms that manage earnings upward issue debt at a lower cost.

\subsection{Research hypotheses}

According to Tang et al. (2014), firms with D\&O insurance have a greater magnitude of discretionary accruals than those without D\&O insurance. In addition, they also find that firms with higher abnormal D\&O insurance coverage have greater magnitude of discretionary accruals. Based on the above, this study assumes D\&O insurance has a significant impact on real earnings management. Liao et al. (2016) confirm a significant positive relationship between D\&O insurance and earnings conservatism. In addition, Chang and Chen (2018) indicated that the protection of D\&O insurance is associated with lower and higher levels of real and accrual-based earnings management, respectively. Furthermore, suggest that the greater the D\&O insurance coverage, the stronger the relationship between D\&O insurance and earnings conservatism. We therefore formulate the following hypotheses:

Hypothesis 1: D\&O insurance has an impact on real earnings management.

Hypothesis 1-1: The purchase of $\mathrm{D} \& \mathrm{O}$ insurance will significantly positively influence on real earnings management.

Hypothesis 1-2: The amount of D\&O insurance purchased will significantly positively influence on real earnings management.

Sengupta (1998) and Francis et al. (2002) found that the better the quality of a company's earnings, the lower the company's capital costs. Liu et al. (2010) demonstrate that before issuing debts, companies will engage earning management to reduce their issuance costs. Based on the above, this study assumes that the extent of earnings management will affect a company's borrowing costs. We therefore formulate the following hypothesis:

Hypothesis 2: Real earnings management has an impact on borrowing costs.

Lin et al. (2013) found that companies purchase D\&O insurance would increase credit risk and lead to higher capital costs. However, Tsai et al. (2017) reveal that a negative association between D\&O liability insurance coverage and the cost of debt and implying that $\mathrm{D} \& \mathrm{O}$ liability insurance plays a monitoring role for Taiwanese firms. Based on the above literature, we therefore formulate the following hypothesis:

Hypothesis 3: D\&O insurance has an impact on an enterprise's borrowing costs.

Hypothesis 3-1: D\&O insurance will significantly negatively affect the debt cost of the enterprise.

Hypothesis 3-2: The greater the amount of D\&O insurance, the greater the impact on the cost of liabilities. 
According to Francis et al. (2002), Sengupta (1998) and Liu et al. (2010) show that earnings management have a significant impact on debt costs. Tsai et al. (2017) indicated that D\&O insurance has s significant impact on the cost of debt. Previous studies have indicated that $\mathrm{D} \& \mathrm{O}$ insurance has a significant negative correlative with the robustness of firm earning (Chung and Wynn,2008), and has larger range of earnings management (Tang et al.,2014), but there are also studies find that amount of $\mathrm{D} \& \mathrm{O}$ insurance has negative relationship with earnings response coefficient (Liao et al.,2015). Furthermore, Chang and Chen (2015) find that D\&O insurance has a moderating effect on the relationship between corporate governance and credit rating. Based on the above, this study assumes that $\mathrm{D} \& \mathrm{O}$ insurance has a moderating effect on the relationship between earnings management and borrowing costs. We therefore formulate the following hypotheses:

Hypothesis 4: D\&O insurance has a moderating effect on real earnings management and borrowing costs.

Hypothesis 4-1: Whether the enterprise purchases D\&O insurance has a moderating effect on real earnings management and borrowing costs.

Hypothesis 4-2: The amount of D\&O insurance has a moderating effect on the actual earnings of the enterprise and its borrowing costs.

\section{Data, Methodology, and Variables}

\subsection{Data and variables}

This study investigates the effect of earnings management and D\&O insurance on borrowing costs. A further analysis attempts to examine whether D\&O insurance intensifies the relationship between earnings management and borrowing costs. Information on earnings management, D\&O insurance, firm characteristics, and borrowing costs are extracted from sample firms' annual reports or from public databases including: the Taiwan Economic Journal (TEJ), Taiwan Stock Exchange Corp. (TSEC), and Market Observation Post System (MOPS). As overproduction as a real earnings management tool is available primarily to firms in the manufacturing industries ( $\mathrm{Ge}$ and Kim,2014), our sample includes all manufacturing firms listed on the Taiwan Stock Exchange (TSE) and Over-the Counter (OTC) for the period 2010 to 2017, which excludes the effect of the global financial crisis. After dropping observations that lacked sufficient financial or corporate governance data, we obtained 5072 firm-year observations.

\subsection{The definition of variables}

\subsubsection{Dependent variables: borrowing cost}

Debt capital represents an important source of company financing and debtholders are important company stakeholders. Park (2000) claim that financial institutions can punish problem companies by changing debt covenants or liquidation agreements. Following the literature (e.g., Francis et al., 2005; Shailer and Wang 2015; Tsai et al., 2017), this study uses the interest rate on the firm's debt to proxy for the borrowing cost, which is defined as interest expense divided by average 
short- and long-term debt during the year.

\subsubsection{Independent variables: Measurement of real earnings management}

According to Roychowdhury (2006), a company will use three methods of activity manipulation for real earnings management, that is, abnormal cash flow from sales manipulation (Abn-CFO), overproduction to reduce the unit cost of goods (AbnProd), and abnormal reduction of discretionary and other operating expenses (AbnDisExp). To capture the effects of earnings management through these three activities in a comprehensive measure, following Zhao et al. (2012) and Yang et al. (2016), this study constructs an overall real earnings management proxy (REM_Index) by summing the three real earnings management measures Abn-CFO, Abn-Prod, and Abn-DisExp. Following previous research (Roychowdhury 2006; Zhao et al., 2012; Yang et al., 2016), this study develops the following four proxies for real earning management.

Sales manipulation activities lead to lower current-period cash flows from operations relative to sales and attempt to temporarily increase price discount or credit terms (Ge and Kim, 2014). The regression model to estimate the abnormal level of cash flows from operations is as follows:

CFO $_{i t} /$ Assets $_{i t-1}=\alpha_{0}\left(1 /\right.$ Assets $\left._{i t-1}\right)+\alpha_{1}\left(\right.$ Sales $_{i t} /$ Assets $\left._{i t-1}\right)+\alpha_{2}\left(\Delta\right.$ Sales $_{i t} /$ Asset $\left._{i t-1}\right)+\varepsilon_{i t}$,

where $C F O$ is cash flow from operating activities, Assets is total assets at the end of the period, Sales is net revenue from sales, $\Delta$ Sales is change in net sales, and $\varepsilon$ is residual items, that is, cash flows from unusual business activities (Abn-CFO).

Overproduction is defined as the company's attempts to produce more goods than necessary and allocate the overhead costs to more units of goods, which results in lower unit costs (Ge and Kim, 2014). Thus, overproduction leads to abnormally low cost of sales. This study applies the following regression model to determine the overproduction cost.

Prod $_{i t} /$ Assetsit $-1=\alpha_{0}\left(1 /\right.$ Assets $\left._{i t-1}\right)+\alpha_{1}\left(\right.$ Sales $_{i t} /$ Assets $\left._{i t-1}\right)+\alpha_{2} \Delta$ Sales $_{i t} /$ Asset $\left._{i t-1}\right)$ $+\alpha_{3}(\Delta$ Salesit $-1 /$ Assetsit -1$)+\varepsilon_{i t}$

where Prod is cost of goods sold plus changes in inventories; Assets is total assets at the end of the period; Sales is net revenue from sales; $\triangle$ Sales is change in net sales; and $\varepsilon$ : is residual items, that is, the abnormal cost of sales (Abn-Prod).

Discretionary expenses are referred to as normal operating expenses. An abnormal reduction in discretionary expenses will lead to abnormally low discretionary expenses relative to sales (Ge and Kim, 2014). The abnormal level of discretionary expenses is estimated as:

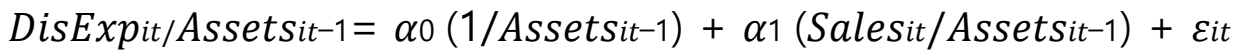

where DisExp is operating expenses minus depreciation and amortisation expenses; Assets is total assets at the end of the period; Sales is net revenue from sales; and $\varepsilon$ : is residual items, that is, the abnormal operating expenses (Abn-DisExp). 
Furthermore, to capture the effects of earnings management through these three activities in a comprehensive measure, consistent with Zhao et al. (2012) and Yang et al. (2016), this study constructs an overall real earnings management proxy (REM-Index) by summing the three real earnings management measures Abn-CFO, Abn-Prod, and Abn-DisExp.

REMIndex=-standardized AbnCFO+standardized AbnProd+standardized AbnDisExp

Real earnings management may have dual outcomes but opposite manipulative purposes. One purpose is positive earnings management to improve corporate earnings and the other is a negative one, to reduce corporate earnings. To manage both types of manipulative earnings and explore the impact of the extent of real earnings management and borrowing costs, following Tang et al. (2014), the overall real earnings management proxy is taken as an absolute value $(|\mathrm{REM}|)$ to measure the magnitude of real earnings management.

\subsubsection{Moderating variable}

It has been argued that, in terms of managerial incentive, the role of $\mathrm{D} \& \mathrm{O}$ insurance has two contrasting effects: effective monitoring and managerial moral hazard (Wynn, 2008). Therefore, D\&O may alter top managers' behaviour under insurance protection. Lin et al. (2013) claim that a company with a high level of D\&O insurance protection will increase its credit risk and lead to higher capital costs. By contrast, due to the monitoring effect, an insured company can effectively reduce the cost of capital (Tsai et al., 2017). Furthermore, Li and Liao (2014) find that firms whose managers are under D\&O insurance coverage have larger spread than uninsured ones, and the spread is greater as the coverage increases. Chang and Chen (2015) also demonstrates that the higher the amount of D\&O insurance, the better the company's credit score. Therefore, this study uses two explanatory variables regarding $\mathrm{D} \& \mathrm{O}$ insurance $(\mathrm{D} \& \mathrm{O})$. First, a dummy variable DOyes is assigned for having (not having) D\&O insurance, and equals 1 if the firm is covered by D\&O insurance or 0 otherwise. Following previous literature ( Lin et al.,2013), the second measurement is the coverage ratio of $\mathrm{D} \& \mathrm{O}$ insurance (DOamt), which is defined as the coverage amount of $\mathrm{D} \& \mathrm{O}$ insurance scaled by the market value of equity at the end of year.

\subsubsection{Control variables}

Boards with different characteristics take different corporate actions and decisions (Coles et al.,2008). Abundant financial research further indicates that characteristics of the board play an effective role in financial reports and may therefore be able to prevent managers from engaging in earnings management (Cornett et al., 2008; Ge and Kim, 2014). Following Cornett et al. (2008), the current study measures board structure variables by the board independence (IND, proportion of independent directors on the board) and CEO/COB leadership duality (DUAL, chief executive officer is also the chairperson of the board). The leadership duality is a dummy 
variable that equals 1 if $\mathrm{CEO}=\mathrm{COB}$ and 0 otherwise. In addition, the stock-holding percentage of all directors (DSHOLD) is selected because it is relevant to corporate governance (Core,1997). The variable of the rate of pledge by the directors (PLEDGE) is also selected as a mechanism used to align managerial incentives with shareholder objectives and reduce agency costs and financial risk (Lin, 2009). The relationship between the audit effect of an accounting firm and real earnings management is not clear. Becker et al. (2010) and Yang et al. (2016) show that large accounting firms have lower margins of earnings management. However, Chi et al. (2011) find that large-scale accounting firms do engage in significant earnings management. Therefore, this study includes the Big Four accounting firms (BIG4) as a control variable to investigate this kind of audit effect.

Several variables for firm-specific characteristics are also included to control for the individual differences among firms. The variable for measuring the financial strength is debt ratio. Debt ratio (LEV) is equal to the ratio of the book value of debts to book value of assets. Large firms have incentive to engage in earnings management (Watts and Zimmerman 1990). We include this variable (Size, the natural logarithm of opening total assets) to control for the effect of firm size on real earnings management. In addition, Liao et al. (2017) find that if companies have better profitability, their credit risk is small. Lim et al. (2017) also confirm that the greater the company's profitability, the lower its financing cost. Several empirical studies further demonstrate that corporate borrowing costs have

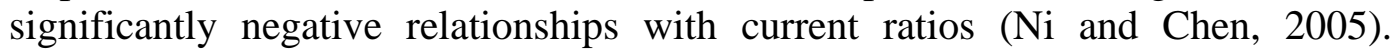
Therefore, to control for individual differences, we include ROA and CR to represent profitability and current ratios, respectively. Descriptions of variables are shown in Table 1.

Table 1: Variable definitions

\begin{tabular}{|l|l|}
\hline Variable & \multicolumn{1}{c|}{ Definition } \\
\hline IR & $\begin{array}{l}\text { Borrowing cost, which is defined as interest expense divided by average short and long term } \\
\text { debt during the year }\end{array}$ \\
\hline REM & $\begin{array}{l}\text { An overall real earnings management proxy by summing the three real earnings management } \\
\text { measures Abn-CFO, Abn-Prod, and Abn-DisExp }\end{array}$ \\
\hline DOyes & Dummy variable that equals 1 if the firm covered with D\&O insurance or 0 otherwise \\
\hline DOamt & Amount of D\&O insurance coverage scaled by the market value of equity at the end of year \\
\hline SIZE & Firm size, measured as natural logarithm of total assets \\
\hline LEV & Debt ratio is equal to the book value of debts to book value of assets \\
\hline CR & Current assets/current liabilities at the end of year \\
\hline ROA & $\begin{array}{l}\text { Return on assets, which is defined as income before extraordinary items/total assets at the end } \\
\text { of year }\end{array}$ \\
\hline DUAL & $\begin{array}{l}\text { Dummy variable which equals 1 if chief executive officer is same as chairperson of the board } \\
\text { and 0 otherwise }\end{array}$ \\
\hline DSHOLD & Stock-holding percentage owned by all directors \\
\hline PLFDGE & The pledge ratio, which equals the ownership-in-pledge ratio of directors of a firm \\
\hline IND & Proportion of independent directors on the board \\
\hline BIG4 & $\begin{array}{l}\text { Dummy variable which equals 1 if accounting audit is serviced by } 4 \text { large-scale accounting } \\
\text { firms and 0 otherwise }\end{array}$ \\
\hline
\end{tabular}




\subsection{Empirical model}

This study attempts to explore the relationship between real earnings management, D\&O insurance, and borrowing costs. Differences between firms with and without $\mathrm{D} \& \mathrm{O}$ insurance coverage could drive differences in firms' earnings management and borrowing costs. For example, if firms select to purchase D\&O insurance according to the extent of earnings management and borrowing costs, a firm's D\&O insurance choice is endogenous. To address this endogeneity issue, we employ the Heckman (1979) two-stage approach to reduce the selection bias.

In the first stage, we estimate a probit model that includes a purchase decision as a dependent variable and determinants of a firms' choice to purchase D\&O insurance as independent variables. These determinants include firm size (SIZE), debit ratio (LEV), return on assets (ROA), return on equity (ROE), the stock-holding percentage of all directors (DSHOLD), the stock-holding percentage of managers (MGHOLD), proportion of independent directors on the board (IND), and membership in high-tech industry (Chang and Lai, 2017). The estimation model is as follows:

$\left(\mathrm{D}_{2} \mathrm{O}_{i t}\right)=\alpha_{0}+\alpha_{1} \mathrm{SIZE}_{i t}+\alpha_{2} \mathrm{LEV}_{i t}+\alpha_{3} \mathrm{ROA}_{i t}+\alpha_{4} \mathrm{ROE}_{i t}+\alpha_{5} \mathrm{DSHOLD}_{i t}+\alpha_{6} \mathrm{MGHOLD}_{i t}$ $+\alpha_{7} \mathrm{IND}_{i t}+\alpha_{8}$ Industry $_{i t}+\varphi$ Year $+\varepsilon_{i t}$

In the second stage, we run the ordinary least squares to investigate the relationship between liability insurance (D\&O) and real earnings management (REM). To investigate the effect of $\mathrm{D} \& \mathrm{O}$ insurance, this study uses a dummy variable (DOyes) and the amount of $\mathrm{D} \& \mathrm{O}$ insurance coverage ratio (DOamt) to proxy for D\&O insurance coverage. Following Yang et al. (2016) and Tang et al. (2014), this study includes firm size (SIZEe), debt ratio (LEV), return on assets (ROA), the stockholding percentage of all directors (DSHOLD), the proportion of independent directors on the board (Indt), whether the chief executive officer is a chairperson of the board (DUAL), the Big Four accounting firms (BIG4), and the industry (Industry) as control variables. In addition, to reduce the endogeneity problem, this survey also includes the selection bias (IMR) computed in the first-stage estimation of Eq. (1) as the control variable. The regression equation is as follows:

$|\mathrm{REM}|=\alpha_{0}+\alpha_{1} \mathrm{D} \& \mathrm{O}_{i t}+\alpha_{2} \mathrm{SIZE}_{i t}+\alpha_{3} \mathrm{LEV}_{i t}+\alpha_{4} \mathrm{ROA}_{i t}+\alpha_{5} \mathrm{DSHOLD}_{i t}+\alpha_{6} \mathrm{IND}_{i t}+$ $\alpha_{7}$ DUALit $+\alpha_{8} \mathrm{BIG}_{i t}+\alpha_{9} \mathrm{IMR}_{i t}+\alpha_{10}$ Industryit $+\varphi$ Year $+\varepsilon_{i t}$

Moreover, this study attempts to test the impact of real earnings management and $\mathrm{D} \& \mathrm{O}$ insurance on borrowing cost and the moderating effect of D\&O insurance on the relationship between these two factors. To investigate the moderating effect of D\&O insurance, we add the interaction terms of $|R E M| \times$ D\&O dummy variable (DOyes) and $|R E M| \times \mathrm{D} \& \mathrm{O}$ insurance coverage ratio (DOamt) separately to equation. Therefore, the empirical testing model is as follows:

$$
\begin{aligned}
& \mathrm{IR}=\alpha_{0}+\alpha_{1}|\mathrm{REM}| i t+\alpha_{2} \mathrm{D}_{2} \mathrm{O}_{i t}+\alpha_{3}|\mathrm{REM}| * \mathrm{D}_{2} \& \mathrm{O}_{i t}+\alpha_{4} \mathrm{SIZE}_{i t}+\alpha_{5} \mathrm{LEV}_{i t}+\alpha_{6} \mathrm{CR}_{i t}+\alpha_{7} \mathrm{ROA}_{i t}+ \\
& \quad \alpha_{8} \mathrm{DSHOLD}_{i t}+\alpha_{9} \mathrm{PLEDGE}_{i t}+\alpha_{10} \mathrm{IND}_{i t}+\alpha_{11} \mathrm{IMR}_{i t}+\alpha_{12} \mathrm{DUAL}_{i t}+\alpha_{13} \text { Industry }_{i t}+\varphi \text { Year } \\
& \quad+\varepsilon_{i t}
\end{aligned}
$$




\section{Empirical Results}

\subsection{Descriptive statistics}

Table 2 provides the summary statistics of the variables used in the primary test. The average borrowing cost of this research sample is 1.833 , which indicates that the average borrowing cost is $1.833 \%$ for publicly listed companies in Taiwan. The mean values of the real earnings management proxies are not large numbers. However, the standard deviation is greater than the mean value, indicating that firms' real earnings management is more dispersed in the research samples. The basic statistics reveal that about $58.5 \%$ of sample firms have D\&O insurance protection. However, the standard deviation is greater than the mean value, indicating that D\&O insurance coverage is more dispersed. The descriptive statistics of Size indicate that the sample firms include both small and large firms. The descriptive statistics further show that more than $88 \%$ of sample companies have external auditors to examine whether the financial statements comply with GAPP.

Table 2: Summary of the Sample Statistics

\begin{tabular}{|c|c|c|c|c|c|}
\hline & Observations & Min. & Max. & Mean & Std. Dev. \\
\hline IR & 5072 & 0.000 & 24.000 & 1.833 & 1.035 \\
\hline REM & 5072 & -169.224 & 57.632 & 0.015 & 3.351 \\
\hline REM $\mid$ & 5072 & 0.000 & 169.224 & 0.586 & 3.300 \\
\hline DOyes & 5072 & 0.000 & 1.000 & 0.585 & 0.497 \\
\hline DOamt $^{1}$ & 5072 & 0.014 & 2555.281 & 81.399 & 140.411 \\
\hline SIZE $^{2}$ & 5072 & 10.704 & 21.949 & 15.427 & 1.461 \\
\hline $\operatorname{LEV}(\%)$ & 5072 & 5.000 & 1281.790 & 49.046 & 37.409 \\
\hline $\mathrm{CR}(\%)$ & 5072 & 1.670 & 1991.990 & 181.792 & 93.663 \\
\hline $\mathrm{ROA}$ & 5072 & -146.730 & 95.780 & 2.319 & 9.569 \\
\hline DSHOLD & 5072 & 0.050 & 96.460 & 22.565 & 14.998 \\
\hline PLFDGE(\%) & 5072 & 0.000 & 100.000 & 7.702 & 15.463 \\
\hline IND & 5072 & 0.000 & 0.800 & 0.191 & 0.139 \\
\hline DUAL & 5072 & 0.000 & 1.000 & 0.346 & - \\
\hline BIG4 & 5072 & 0.000 & 1.000 & 0.888 & - \\
\hline
\end{tabular}

Table 3 provides the Pearson correlation matrix of the variables involved. The borrowing cost is positively related to absolute value (|REM|), D\&O insurance amount, debt ratio, leadership duality, and pledge ratio, which indicates that firms with the characteristics of real earnings management, more insurance coverage, high debt ratio, and leadership duality will be charged higher borrowing costs. Real earnings management is positively related to D\&O insurance amount, firm size, and pledge ratio. The correlation coefficient between the other independent variables is less than 0.6 , which indicates the research model has no collinearity problem. 
Table 3: Pearson's Correlation matrix

\begin{tabular}{|c|c|c|c|c|c|c|c|c|c|c|c|c|c|}
\hline & IR & $|\mathrm{REM}|$ & DOyes & DOamt & SIZE & LEV & $\mathrm{CR}$ & ROA & DSHOLD & PLFDGE & IND & DUAL & BIG4 \\
\hline IR & 1 & & & & & & & & & & & & \\
\hline$|\mathrm{REM}|$ & $.027^{*}$ & 1 & & & & & & & & & & & \\
\hline DOyes & $-.143^{* * *}$ & -.003 & 1 & & & & & & & & & & \\
\hline DOamt & $.053^{* * *}$ & $.526^{* * * *}$ & $.080^{* * *}$ & 1 & & & & & & & & & \\
\hline SIZE & $-.192^{* *}$ & $.093^{* * * *}$ & $.262^{* * *}$ & -.018 & 1 & & & & & & & & \\
\hline LEV & $.195^{* * *}$ & .019 & $-.068^{* * * *}$ & $.060^{* * *}$ & .017 & 1 & & & & & & & \\
\hline $\mathrm{CR}$ & $-.181^{* * *}$ & 0.01 & $.050^{* * *}$ & $-.026^{*}$ & $-.151^{* * * *}$ & $-.327^{* * *}$ & 1 & & & & & & \\
\hline ROA & $-.247^{* * *}$ & -0.016 & $.085^{* * *}$ & $-.077^{* * *}$ & $.255^{* * *}$ & $-.200^{* * * *}$ & $.202^{* * *}$ & 1 & & & & & \\
\hline DSHOLD & $-.032^{* *}$ & $-.035^{* *}$ & $-.172^{* * *}$ & .007 & -.240 & $-.049^{* * *}$ & $-.049^{* * *}$ & -.008 & 1 & & & & \\
\hline PLFDGE & $.084^{* * *}$ & $.049^{* * * *}$ & .022 & $.042^{* * *}$ & $.154^{* * *}$ & $.104^{* * *}$ & $-.068^{* * *}$ & $-.042^{* * *}$ & $-.114^{* * *}$ & 1 & & & \\
\hline INDDIR & $-.036^{* *}$ & .016 & $.227^{* * *}$ & .013 & -.016 & $-.032^{* *}$ & $.045^{* * * *}$ & -.012 & $-.057^{* * *}$ & $-.065^{* * *}$ & 1 & & \\
\hline DUAL & $.065^{* * *}$ & -.014 & .006 & .012 & $-.132^{* * *}$ & $.028^{* * *}$ & $0.026^{*}$ & $-.062^{* * *}$ & $-.048^{* * *}$ & -.013 & -.005 & 1 & \\
\hline BIG4 & $-.131^{* * *}$ & .005 & $.132^{* * * *}$ & .005 & $.134^{* * * *}$ & $-.096^{* * *}$ & $.042^{* * * *}$ & $.077^{* * *}$ & $-.027^{*}$ & $-.045^{* * *}$ & $.136^{* * *}$ & $-.081^{* * * *}$ & 1 \\
\hline
\end{tabular}




\subsection{Regression results}

\subsubsection{The effect of D\&O insurance protection on REM}

The empirical evidence in Table 4 reveals that real earning management is significantly negatively correlated with the $\mathrm{D} \& \mathrm{O}$ insurance protection decision (DOyes) is consistent with Chang and Chen (2018); however, its relationship with the D\&O insurance amount is insignificant. The H1-1 and H1-2 are not support in this study. The negative coefficient is consistent with the effective monitoring perspective. The result indicates that highly protected managers are less likely to engage in sales manipulation or overproduction or cut discretionary expenses to manipulate earnings under more scrutiny. In contrast, the results indicate that REM has a significantly positive relationship with board independence. This result implies that stronger board governance is associated with higher levels of real earnings management, which is consistent with the findings of Ge and Kim (2014). It is therefore possible that managers are more likely to engage in real earnings management when they are faced with tough monitoring from independent directors (Ge and Kim, 2014).

With respect to the other control variables, the sign of the coefficient for Size shows that large firms are generally more likely to perform real earnings management, indicating that larger firms have incentives to engage in real earnings management, most likely because the cost of real earnings management is lower ( $\mathrm{Ge}$ and Kim,2014). Previous research finds that accounting choices primarily reflect companies' financial difficulties rather than their desire to manage income (e.g. Ahearne et al., 2016). Therefore, firms with a high debt ratio (LEV) are less likely to manipulate earnings, probably due to the concern that unusually high levels of debt would draw the attention of stakeholders or external auditors. The sign of the estimated coefficient for stock-holding percentage of all directors (DSHOLD) suggests that firms with a higher proportion of shares held by directors are less likely to manage earnings. Selection bias has a significantly positive relationship with real earnings management, which indicates that this survey can effectively control the endogeneity problem for the demand for $\mathrm{D} \& \mathrm{O}$ insurance. This result is consistent with Tang et al. (2014), Liao (2016), and Yang et al. (2016). 
Table 4: Regression results of D\&O insurance on REM

\begin{tabular}{|c|c|c|}
\hline Dependent variable: $\mid$ REM $\mid$ & Panel A $^{1}$ & Panel B \\
\hline Constant & $\begin{array}{l}-77.645 \\
(1.442)\end{array}$ & $\begin{array}{c}-280.224^{* * *} \\
(2.875)\end{array}$ \\
\hline DOyes & $\begin{array}{c}-6.042^{* * * *} \\
(6.343)\end{array}$ & \\
\hline DOamt & & $\begin{array}{c}0.000 \\
(0.382)\end{array}$ \\
\hline SIZE & $\begin{array}{l}0.617^{* * *} \\
(8.475)\end{array}$ & $\begin{array}{l}1.149^{* * * *} \\
(7.676)\end{array}$ \\
\hline LEV & $\begin{array}{c}-0.005^{* * * *} \\
(3.031)\end{array}$ & $\begin{array}{c}-0.038^{* * *} \\
(5.170)\end{array}$ \\
\hline ROA & $\begin{array}{l}-0.007 \\
(1.329)\end{array}$ & $\begin{array}{l}-0.010 \\
(0.921)\end{array}$ \\
\hline DSHOLD & $\begin{array}{l}-0.026^{* * * *} \\
(5.466)\end{array}$ & $\begin{array}{l}-0.048^{* * * *} \\
(5.324)\end{array}$ \\
\hline IND & $\begin{array}{l}3.461^{* * * *} \\
(6.730)\end{array}$ & $\begin{array}{l}5.600^{* * * *} \\
(5.875)\end{array}$ \\
\hline DUAL & $\begin{array}{l}-0.026 \\
(0.266)\end{array}$ & $\begin{array}{l}-0.136 \\
(0.843)\end{array}$ \\
\hline BIG4 & $\begin{array}{c}0.062 \\
(0.412)\end{array}$ & $\begin{array}{c}0.020 \\
(0.068)\end{array}$ \\
\hline $\mathrm{IMR}^{2}$ & $\begin{array}{l}5.967^{* * * *} \\
(6.222)\end{array}$ & $\begin{array}{c}12.422^{* * * *} \\
(6.026)\end{array}$ \\
\hline Industry effect & Yes & Yes \\
\hline Year effect & Yes & Yes \\
\hline Observations & 5072 & 2949 \\
\hline Adjusted $\mathrm{R}^{2}$ & 0.22 & 0.023 \\
\hline
\end{tabular}

\subsubsection{The effect of REM on borrowing cost}

Panel A in Table 5 examines the effect of real earnings management on borrowing cost. The positive and significant coefficient between real earnings management and borrowing cost supports H2. This result implies that firms with higher REM propensity are associated with high levels of borrowing cost, which is consistent with Sengupta's (1998) findings, namely, that companies with higher earnings management quality can obtain lower interest rates when issuing debt, indicating that if the firm engages in earnings management, the quality of earnings management will be lower and the interest rate will be higher.

As expected, firm size, current ratio, and return on assets have significantly negative relationships with borrowing cost. The results imply that larger firms with higher current assets and more profitability will lower borrowing costs. Furthermore, the sign of the estimated coefficients for debt ratio suggests that high-leverage firms are more likely to default and this characteristic is therefore expected to be associated with higher borrowing costs. Regarding the corporate governance variables, the high level of shares held by directors and an independent director on the board 
lowers borrowing costs, indicating that stronger board governance will result in lower cost of debt through strong incentives and capabilities to devote resources to monitoring. However, the pledge ratio of directors and leadership duality have significantly positive relationships with borrowing cost. The result implies that in such firms, insiders have incentives to expropriate creditors through various selfdealing activities. Many of these activities may increase default risk and, as a consequence, the cost of borrowing (Lin et al., 2013).

\subsubsection{The effect of $D \& O$ insurance protection on borrowing cost}

The results in panel $\mathrm{B}$ and $\mathrm{D}$ of Table 5 examine the effect of $\mathrm{D} \& \mathrm{O}$ insurance on the cost of borrowing. As can be seen from panel B, we find strong evidence that D\&O insurance purchase decision is negatively associated with borrowing cost and provides evidence in support of hypothesis H3a. The result is also consistent with previous studies (e.g. Yuan et al., 2016; Tsai et al., 2017) and shows that D\&O insurance purchase policy has an effect of reducing borrowing costs. However, from the result from panel $\mathrm{D}$, we find that high levels of $\mathrm{D} \& \mathrm{O}$ insurance amount are associated with higher cost of borrowing. The possible reason is that the larger D\&O insurance amounts has increased the incentives for self-interested speculation and a moral hazard has occurred (Lee et al.,2020), so that increased borrowing cost. Our evidence is consistent with the findings that high levels of D\&O insurance amount may alter top managers' behavior to increase credit risk, and such behavior is reflected in the terms under which lenders will provide capital to the firm (Lin et al. 2013). In terms of the control variables, the results in Table $\mathrm{V}$ are generally in the predicted directions and are consistent with the previous literature and similar to those regarding the effect of REM on borrowing cost.

\subsubsection{The moderating effect of D\&O insurance}

To investigate the moderating effect of D\&O insurance protection, this study uses a D\&O dummy and D\&O insurance amount to proxy for the D\&O protection and adds the interaction terms of $|\mathrm{REM}| \mathrm{x}$ D\&O insurance dummy and $|\mathrm{REM}| \mathrm{x} \mathrm{D} \& \mathrm{O}$ amount separately to the equation.

Panels $\mathrm{C}$ and $\mathrm{E}$ in Table 5 analyses the moderating effect of D\&O liability protection on the relationship between real earnings management and cost of borrowing. The estimated signs of real earnings management, D\&O coverage, and the control variables are the same as those estimated in panels B and D. The coefficient of the interaction term $|R E M| x D \& O$ insurance dummy, is significantly negative, indicating that $\mathrm{D} \& \mathrm{O}$ insurance protection mitigates the relationship between real earnings management and borrowing cost. This condition indicates that borrowing costs decrease more for firms under D\&O insurance protection than those without protection. The coefficient of the interaction term $|\mathrm{REM}| \mathrm{x}$ D\&O amount is significantly positive, indicating that the amount of D\&O insurance intensifies the relationship between real earnings management and borrowing cost. As firms increase their real earnings management, borrowing costs increase more 
for the firms with relatively higher amounts of $\mathrm{D} \& \mathrm{O}$ insurance than for those whose D\&O insurance amounts are relatively low. This result illustrates that management manipulation schemes have more impacts on cost of borrowing for the firms with relatively greater $\mathrm{D} \& \mathrm{O}$ insurance amount.

Table 5: Regression results of REM, D\&O insurance and borrowing cost

\begin{tabular}{|c|c|c|c|c|c|}
\hline Dependent variable: IR & Panel $\mathbf{A}^{1}$ & Panel B & Panel C & Panel D & Panel E \\
\hline Constant & $\begin{array}{l}-4.309 \\
(0.331)\end{array}$ & $\begin{array}{c}-129.551^{* * * *} \\
(8.194)\end{array}$ & $\begin{array}{c}-127.941^{* * * *} \\
(8.094)\end{array}$ & $\begin{array}{c}117.012^{* * *} \\
(6.484)\end{array}$ & $\begin{array}{c}-118.212^{\text {*** }} \\
(6.542)\end{array}$ \\
\hline$|\mathrm{REM}|$ & $\begin{array}{c}0.011^{* * * *} \\
(2.740)\end{array}$ & & $\begin{array}{c}0.044^{* * * *} \\
(3.270)\end{array}$ & & $\begin{array}{c}-0.005 \\
(1.211)\end{array}$ \\
\hline DOyes & & $\begin{array}{l}-3.900^{* * * *} \\
(13.428) \\
\end{array}$ & $\begin{array}{c}-3.770^{* * * *} \\
(12.848)\end{array}$ & & \\
\hline $\mid$ REM|*DOyes & & & $\begin{array}{c}-0.043^{* * * *} \\
(3.018)\end{array}$ & & \\
\hline DO amt & & & & $\begin{array}{l}0.001^{* * * *} \\
(4.498)\end{array}$ & $\begin{array}{l}0.000^{* * * *} \\
(4.135)\end{array}$ \\
\hline $\mid$ REM|*DOamt & & & & & $\begin{array}{l}0.000^{* *} \\
(2.357)\end{array}$ \\
\hline SIZE & $\begin{array}{c}-0.153^{* * *} \\
(14.645)\end{array}$ & $\begin{array}{c}0.126^{* * * *} \\
(5.534)\end{array}$ & $\begin{array}{c}0.117^{* * * *} \\
(5.054)\end{array}$ & $\begin{array}{c}0.095^{* * * *} \\
(3.399)\end{array}$ & $\begin{array}{l}0.098^{* * * *} \\
(3.473)\end{array}$ \\
\hline LEV & $\begin{array}{c}0.003^{* * * *} \\
(7.703)\end{array}$ & $\begin{array}{c}0.000 \\
(0.500)\end{array}$ & $\begin{array}{c}0.000 \\
(0.482)\end{array}$ & $\begin{array}{c}0.005^{* * * *} \\
(3.497)\end{array}$ & $\begin{array}{l}0.005^{* * * *} \\
(3.322)\end{array}$ \\
\hline$\overline{C R}$ & $\begin{array}{c}-0.002^{* * * * *} \\
(10.209)\end{array}$ & $\begin{array}{c}-0.001^{* * * *} \\
(5.421)\end{array}$ & $\begin{array}{c}-0.001^{* * * *} \\
(5.723)\end{array}$ & $\begin{array}{c}0.000 \\
(1.373)\end{array}$ & $\begin{array}{c}0.000 \\
(1.398)\end{array}$ \\
\hline ROA & $\begin{array}{c}-0.015^{* * * *} \\
(9.893)\end{array}$ & $\begin{array}{c}-0.012^{* * * *} \\
(7.483)\end{array}$ & $\begin{array}{c}-0.011^{* * * *} \\
(7.288)\end{array}$ & $\begin{array}{c}-0.014^{* * * *} \\
(7.007)\end{array}$ & $\begin{array}{c}-0.014^{* * * *} \\
(6.885)\end{array}$ \\
\hline DSHOLD & $\begin{array}{c}-0.005^{* * * *} \\
(5.790)\end{array}$ & $\begin{array}{l}-0.019^{* * * *} \\
(13.834)\end{array}$ & $\begin{array}{l}-0.019^{* * * *} \\
(13.444)\end{array}$ & $\begin{array}{c}-0.014^{* * * *} \\
(8.570)\end{array}$ & $\begin{array}{c}-0.014^{* * * *} \\
(8.613)\end{array}$ \\
\hline PLFDGE & $\begin{array}{c}0.005^{* * * *} \\
(5.644)\end{array}$ & $\begin{array}{c}0.005^{* * * *} \\
(5.867)\end{array}$ & $\begin{array}{l}0.005^{* * * *} \\
(5.953)\end{array}$ & $\begin{array}{l}0.005^{* * *} \\
(5.426)\end{array}$ & $\begin{array}{l}0.005^{* * * *} \\
(5.363)\end{array}$ \\
\hline IND & $\begin{array}{l}-0.188^{*} \\
(1.735)\end{array}$ & $\begin{array}{l}1.313^{* * * *} \\
(8.595)\end{array}$ & $\begin{array}{l}1.257^{* * * *} \\
(8.168)\end{array}$ & $\begin{array}{c}0.981^{* * * *} \\
(5.552)\end{array}$ & $\begin{array}{l}0.994^{* * * *} \\
(5.591)\end{array}$ \\
\hline DUAL & $\begin{array}{l}0.062^{* * *} \\
(2.143)\end{array}$ & $\begin{array}{c}0.045 \\
(1.600)\end{array}$ & $\begin{array}{c}0.044 \\
(1.566)\end{array}$ & $\begin{array}{l}-0.004 \\
(0.129)\end{array}$ & $\begin{array}{l}-0.005 \\
(0.173)\end{array}$ \\
\hline $\mathrm{IMR}^{2}$ & & $\begin{array}{l}3.777^{* * *} \\
(12.927)\end{array}$ & $\begin{array}{l}3.670^{* * * *} \\
(12.464)\end{array}$ & $\begin{array}{c}2.598^{* * * *} \\
(6.802)\end{array}$ & $\begin{array}{l}2.624^{* * * *} \\
(6.829)\end{array}$ \\
\hline Industry effect & Yes & Yes & Yes & Yes & Yes \\
\hline Year effect & Yes & Yes & Yes & Yes & Yes \\
\hline Observations & 5072 & 5072 & 5072 & 2949 & 2949 \\
\hline Adjusted $\mathrm{R}^{2}$ & 0.135 & 0.166 & 0.167 & 0.169 & 0.170 \\
\hline
\end{tabular}

\subsection{Robustness test}

As one of the components of discretionary expenses, $R \& D$ investment is crucial to the firm's innovation activities (Tsao et al., 2015). Ge and Kim (2014) claim that managers can abnormally reduce $\mathrm{R} \& \mathrm{D}$ investment to inflate current earnings and those discretionary expenses inflate earnings immediately at the expense of future payoff. Balkin et al. (2000) further find that the impact of management initiates on $R \& D$ investment for high-technology (i. e. $R \& D$-intensive) firms is different from 
that for low-technology firms. To increase the power of our tests, this study further investigates the association of real earnings management, D\&O insurance, and cost of debt for various industries. We therefore divide our sample into two sub samples, electronics (high technology) and non-electronics industries and run Models (2) and (3).

First, Table 6 provides robust results indicating that real earnings management and $\mathrm{D} \& \mathrm{O}$ insurance, which is consistent with the findings for manufacturing industries presented in Table 4. However, we do not find significant relationships for the nonelectronics industry. Moreover, Table 7 presents the empirical results among REM, amount of D\&O insurance, and borrowing costs. Overall, the effects of REM and D\&O insurance on borrowing costs are largely consistent with those in Table 5.

Table 6: Regression results of D\&O insurance on REM by industries

\begin{tabular}{|c|c|c|}
\hline Dependent variable: |REM| & Electronic $^{1}$ & Non-Electronic \\
\hline Constant & $\begin{array}{c}-77.876 \\
(1.105) \\
\end{array}$ & $\begin{array}{l}82.250^{*} \\
(1.748) \\
\end{array}$ \\
\hline DOyes & $\begin{array}{c}-6.498^{* * * *} \\
(5.180)\end{array}$ & $\begin{array}{c}0.823 \\
(0.777)\end{array}$ \\
\hline SIZE & $\begin{array}{c}0.743^{* * * *} \\
(8.023) \\
\end{array}$ & $\begin{array}{l}-0.208^{* *} \\
(2.316) \\
\end{array}$ \\
\hline LEV & $\begin{array}{l}-0.005^{* * *} \\
(2.462)\end{array}$ & $\begin{array}{c}0.005 \\
(1.292)\end{array}$ \\
\hline ROA & $\begin{array}{l}-0.012^{*} \\
(1.759)\end{array}$ & $\begin{array}{c}0.003 \\
(0.661)\end{array}$ \\
\hline DSHOLD & $\begin{array}{c}-0.029^{* * * *} \\
(4.460) \\
\end{array}$ & $\begin{array}{c}0.002 \\
(0.542) \\
\end{array}$ \\
\hline IND & $\begin{array}{l}3.684^{* * * *} \\
(5.386)\end{array}$ & $\begin{array}{c}-0.388 \\
(0.757)\end{array}$ \\
\hline DUAL & $\begin{array}{c}-0.069 \\
(0.520)\end{array}$ & $\begin{array}{c}0.077 \\
(1.215)\end{array}$ \\
\hline BIG4 & $\begin{array}{c}0.045 \\
(0.199) \\
\end{array}$ & $\begin{array}{c}0.078 \\
(0.989) \\
\end{array}$ \\
\hline$\overline{\text { IMR }^{2}}$ & $\begin{array}{l}6.423^{* * * *} \\
(5.057)\end{array}$ & $\begin{array}{l}-1.043^{*} \\
(0.982)\end{array}$ \\
\hline Industry effect & Yes & Yes \\
\hline Year effect & Yes & Yes \\
\hline Observations & 3622 & 1450 \\
\hline Adjusted $\mathrm{R}^{2}$ & 0.25 & 0.32 \\
\hline
\end{tabular}

Table 7 analyses D\&O insurance and its moderating effects on the electronic versus non-electronic firms' borrowing costs. More importantly, we find a robust negative relationship and moderating effect of $\mathrm{D} \& \mathrm{O}$ insurance purchasing decision for electronics firms only, indicating that firms in the electronics industry use D\&O insurance as a complement to monitor management behavior regarding corporate governance. Regarding the effect of D\&O insurance amount, the empirical results 
reveal that there is an insignificantly moderating effect for non-electronics firms, partially supporting hypotheses. Regarding the firm-specific and governance control variables, the empirical results are largely consistent with previous findings.

Table 7: Regression results of REM, D\&O insurance and borrowing cost by industries

\begin{tabular}{|c|c|c|c|c|}
\hline \multirow[t]{2}{*}{ Dependent variable: IR } & \multicolumn{2}{|c|}{ Electronic } & \multicolumn{2}{|c|}{ Non-Electronic } \\
\hline & Panel $\mathrm{A}^{1}$ & Panel B & Panel C & Panel D \\
\hline Constant & $\begin{array}{c}-139.733^{* * *} \\
(8.693)\end{array}$ & $\begin{array}{c}-134.879^{* * * *} \\
(6.852)\end{array}$ & $\begin{array}{c}5.892 \\
(0.121)\end{array}$ & $\begin{array}{l}-63.571 \\
(1.313)\end{array}$ \\
\hline $\mid$ REM $\mid$ & $\begin{array}{l}0.038^{* * *} \\
(2.660)\end{array}$ & $\begin{array}{l}-0.006 \\
(1.408)\end{array}$ & $\begin{array}{c}0.065^{*} \\
(1.930)\end{array}$ & $\begin{array}{c}0.028 \\
(0.758)\end{array}$ \\
\hline DOyes & $\begin{array}{l}-3.489^{* * *} \\
(11.458)\end{array}$ & & $\begin{array}{l}-1.311 \\
(1.192)\end{array}$ & \\
\hline $\mid$ REM|*DOyes & $\begin{array}{l}-0.036^{* *} \\
(2.445) \\
\end{array}$ & & $\begin{array}{l}-0.097^{*} \\
(1.692) \\
\end{array}$ & \\
\hline DOamt & & $\begin{array}{l}0.000^{* *} \\
(1.987)\end{array}$ & & $\begin{array}{c}0.002^{* * *} \\
(6.012)\end{array}$ \\
\hline |REM|*DOamt & & $\begin{array}{l}0.000^{* * *} \\
(2.779)\end{array}$ & & $\begin{array}{c}0.000 \\
(1.566)\end{array}$ \\
\hline SIZE & $\begin{array}{l}0.114^{* * * *} \\
(4.922)\end{array}$ & $\begin{array}{l}0.113^{* * * *} \\
(3.684)\end{array}$ & $\begin{array}{c}-0.122 \\
(1.301)\end{array}$ & $\begin{array}{c}0.058 \\
(0.673) \\
\end{array}$ \\
\hline LEV & $\begin{array}{c}0.000 \\
(0.466)\end{array}$ & $\begin{array}{l}0.003^{*} \\
(1.718)\end{array}$ & $\begin{array}{l}0.012^{* * *} \\
(2.970)\end{array}$ & $\begin{array}{l}0.008^{* *} \\
(2.003)\end{array}$ \\
\hline $\mathrm{CR}$ & $\begin{array}{c}-0.001^{* * * *} \\
(6.269)\end{array}$ & $\begin{array}{c}-0.001^{* * *} \\
(2.634) \\
\end{array}$ & $\begin{array}{c}0.000 \\
(1.014)\end{array}$ & $\begin{array}{c}0.000 \\
(0.704) \\
\end{array}$ \\
\hline $\mathrm{ROA}$ & $\begin{array}{c}-0.011^{* * *} \\
(7.057)\end{array}$ & $\begin{array}{c}-0.015^{* * *} \\
(6.853)\end{array}$ & $\begin{array}{c}-0.013^{* * *} \\
(2.971) \\
\end{array}$ & $\begin{array}{l}-0.006 \\
(1.297)\end{array}$ \\
\hline DSHOLD & $\begin{array}{l}-0.016^{* * *} \\
(10.802)\end{array}$ & $\begin{array}{c}-0.013^{* * * *} \\
(6.842)\end{array}$ & $\begin{array}{c}-0.013^{* * *} \\
(2.897)\end{array}$ & $\begin{array}{c}-0.017^{\text {**** }} \\
(4.055)\end{array}$ \\
\hline PLFDGE & $\begin{array}{l}0.004^{* * *} \\
(3.994)\end{array}$ & $\begin{array}{l}0.005^{* * *} \\
(4.639)\end{array}$ & $\begin{array}{l}0.008^{* * *} \\
(4.192)\end{array}$ & $\begin{array}{l}0.005^{* *} \\
(2.521)\end{array}$ \\
\hline IND & $\begin{array}{l}1.137^{* * *} \\
(7.115)\end{array}$ & $\begin{array}{l}1.049^{* * * *} \\
(5.265)\end{array}$ & $\begin{array}{c}0.316 \\
(0.593) \\
\end{array}$ & $\begin{array}{c}0.812^{*} \\
(1.673)\end{array}$ \\
\hline DUAL & $\begin{array}{c}0.014 \\
(0.483)\end{array}$ & $\begin{array}{l}-0.018 \\
(0.525)\end{array}$ & $\begin{array}{l}0.145^{\text {** }} \\
(2.199)\end{array}$ & $\begin{array}{c}0.042 \\
(0.666)\end{array}$ \\
\hline $\mathrm{IMR}^{3}$ & $\begin{array}{l}3.342^{* * * *} \\
(10.879)\end{array}$ & $\begin{array}{c}2.864^{* * * *} \\
(6.588)\end{array}$ & $\begin{array}{c}1.340 \\
(1.216)\end{array}$ & $\begin{array}{c}1.868^{*} \\
(1.796)\end{array}$ \\
\hline Industry effect & Yes & Yes & Yes & Yes \\
\hline Year effect & Yes & Yes & Yes & Yes \\
\hline Observations & 3622 & 3622 & 1450 & 1450 \\
\hline Adjusted $\mathrm{R}^{2}$ & 0.192 & 0.168 & 0.148 & 0.220 \\
\hline
\end{tabular}




\section{Conclusion}

Using a sample in an emerging market, (as Taiwan), spanning 2010 to 2017, this study investigates the effect of real earnings management and $\mathrm{D} \& \mathrm{O}$ insurance on borrowing costs. A further analysis attempts to investigate whether D\&O insurance intensifies management manipulation activities by examining its moderating effect on the relationship between real earnings management and borrowing costs. To avoid the self-selection bias resulting from the D\&O insurance purchase decision, this study uses two-stage regression to control for this potential endogeneity. The results contribute to the literature from the following aspects.

First, consistent with Sengupta (1998) and Francis et al. (2002), the results reveal that real earnings management has a significantly positive relationship with the firm's borrowing costs. The results indicate that the lower the earnings quality, the higher the borrowing costs. Moreover, the use of real earnings management does not effectively reduce the borrowing costs but increases the firm's operational risk. Second, as real earnings management increases the firm's risk, regulators suggest that publicly listed firms purchase $\mathrm{D} \& O$ liability insurance to reduce the risk associated with possible faults of top managers. This study finds that D\&O insurance positively moderates the relationship between real earnings management and borrowing cost.

Third, this study investigates whether the relationship between real earnings management and borrowing costs varies with the type of industry. After dividing manufacturing samples into the electronics and non-electronics industries, the moderating effect of $\mathrm{D} \& \mathrm{O}$ insurance appears only in electronics industries, implying that $\mathrm{D} \& \mathrm{O}$ insurance exacerbates $\mathrm{R} \& \mathrm{D}$-intensive industries' earnings management.

Finally, the empirical results provide meaningful implications for regulators. There is controversy over whether D\&O insurance protection benefits shareholders. Some researchers argue that $\mathrm{D} \& \mathrm{O}$ insurance protection entrenches managers while others believe it allows managers to align interests with shareholders and long-term company goals. In addition, our results imply that $\mathrm{D} \& \mathrm{O}$ insurance protection may benefit shareholders in the sense that they alleviate managerial incentives for real earnings management to lower the firm's borrowing costs effectively. Overall, our findings suggest that $\mathrm{D} \& \mathrm{O}$ insurance protection can lower corporate borrowing costs. However, as the amount of $\mathrm{D} \& \mathrm{O}$ insurance protection reaches a certain amount, there may be unintended consequences in terms of strengthening earnings manipulation and affecting the cost of debt in different ways. The results have practical implications for manufacturing industries, and provide Taiwanese experience for development of emerging market. 


\section{References}

[1] Ahearne, M.J., Boichuk, J.P., Chapman, C.J., and Steenburgh, T.J. (2016). Real earnings management in sales, Journal of Accounting Research, Vol.54 No.5, pp.1233-1266.

[2] Balkin, D., Markman, G. and Gomez-Mejia, L. (2000). Is CEO pay in high technology firms related to innovation ?, Academy of Management Journal, Vol. 43, pp.1118-1129.

[3] Becker, C. L., Defond, M. L., Jiambalvo, J. and Subramanyam, K.R. (2010). The Effect of Audit Quality on Earnings Management, Contemporary Accounting Research, Vol.15 No.1, pp.1-24.

[4] Bhagat, S., Brickley, J. A. and Coles, J. L. (1987). Managerial indemnification and liability insurance: The effect on shareholder wealth, Journal of Risk and Insurance, Vol.54 No.3, pp.721-736.

[5] Chang, C.C and Chen, C.W, (2018). Directors' and officers' liability insurance and the trade-off between real and accrual-based earnings management, AsiaPacific Journal of Accounting and Economics, Vol.25 No.1-2,pp.199-217.

[6] Chang, W. W. and Lai, J. M. (2017).The Influence of Life Cycle on the Demand for Directors' and Officers' Liability Insurance, Journal of Management \& Systems, Vol.24 No.2, pp. 215-257.

[7] Chang, Y. and Chen, H. Y. (2015). Directors' and Officers' Liability Insurance and Credit Score, Cross-Sreait Banking and Finance, Vol.3 No.3, pp.73-112.

[8] Chi, W., Lisic, L. L., and Pevzner, M. (2011). Is Enhanced audit quality associated with greater real earnings management?, Accounting Horizons, Vol. 25 No2,pp. 315-335.

[9] Chung, H. H. and Wynn, J. P. (2008). Managerial legal liability coverage and earnings conservatism, Journal of Accounting and Economics. Vol.46 No1, pp.135-153.

[10] Cohen, D. A., Dey, A. and Lys, T. Z. (2008). Real and accrual-based earnings management in the pre-and post-sarbanes-oxley periods, The Accounting Review, Vol. 83 No.3, pp. 757-787.

[11] Coles, J. L., Daniel, N. D., and Naveen, L. (2008). Boards: Does one size fit all? , Journal of Financial Economics, Vol.87, pp.329-356.

[12] Core, J. (1997). On the corporate demand for directors' and officers' Insurance', Journal of Risk and Insurance, Vol. 64 No.1, pp. 63-87.

[13] Cornett, M. M., Marcus, A. J., and Tehranian, H. (2008). Corporate governance and pay-for-performance: The impact of earnings management. Journal of Financial Economics, Vol.87 No.2, pp.357-373.

[14] Deng, X. and Ong, S. E. (2018). Real earnings management, liquidity risk and REITs SEO dynamics, The Journal of Real Estate Finance and Economics, Vol. 56 No.3, pp.410-442.

[15] Francis, J., LaFond, R., Olsson, P., and Schipper, K. (2002). The market pricing of earnings quality, Working paper, Duke University and University of Wisconsin. 
[16] Gao, S. and Gas, J.(2016). Advances in Social Science, Education and Humanities Research (ASSEHR), Vol. 75,pp.89-192.

[17] Ge, W. and Kim, J-B. (2014). Real earnings management and the cost of new corporate bonds, Journal of Business Research, Vol.67, pp. 641-664.

[18] Gunny, K. A. (2010). The relation between earnings management using real activities manipulation and future performance: Evidence from meeting earnings benchmarks, Contemporary Accounting Research, Vol.27 No.3. pp. 855-888.

[19] Gutierrez, M. (2003). An economic analysis of corporate directors' fiduciary duties, The RAND Journal of Economics, Vol 34 No.3.pp,516-535.

[20] Healy, P. M. and Wahlen, J. M. (1999). A review of the earnings management literature and Its implications for standard setting. Accounting Horizons, Vol.13 No4, pp.365-383.

[21] Heckman, J. J. (1979). Sample selection bias as a specification error, Econometrica Vol.47 No, pp.153-161.

[22] Holderness, O. G. (1990). Liability insurers as corporate monitors, International Review of Law and Economics, Vol.10 No2, pp.115-129

[23] Houston, J. and James, C. (1996). Bank information monopolies and the mix of private and public debt claims, The Journal of Financial, Vol. 51 No5, pp. 1863-1889.

[24] Jia, N. and Tang, X. (2018). Directors' and officers' liability insurance, independent director behavior and governance effect, The journal of risk and insurance, Vol. 85 No4, pp.1013-1054.

[25] Lee, J.Z., and Tang, L.F. (2019). The effect of directors' and officers' liability insurance on corporate tax avoidance, Academia Economic Papers, Vol.47 No.3, pp.485-524.

[26] Lee, J.Z., Tang, L.F. and Lu, H.J. (2020). The relationship between directors' and officers' liability insurance and firm value: The perspective of stock investors, Review of Securities and Futures Markets, Vol.32 No.4, pp.31-72.

[27] Li, K.F, and Liao, Y.P., (2014). Directors' and officers' liability insurance and investment efficiency: Evidence from Taiwan. Pacific-Basin finance journal Vol.29, pp.18-34.

[28] Liao, H. M., Tang, L. F. and Lee, J. Z. (2015). The effect of directors' and officers' liability insurance on stock investors' perceptions of earning quality, Chiao Da Management Review, Vol.35 No2, pp.113-148.

[29] Liao, H. M., Tang, L. F. and Lee, J. Z. (2016). Directors' and officers' liability and earnings conservatism, Journal of Accounting Review, Vol.63, pp.109150.

[30] Liao, H. M., Tang, L. F. and Lee, J. Z. (2017). The effect of directors' and officers' liability insurance on firms' credit ratings, NTU Management Review Vol.27 No.4, pp.75-104.

[31] Lim, S. C., Mann, S. C. and Mihov, V. T. (2017). Do operating leases expand credit capacity? Evidence from borrowing costs and credit ratings, Journal of Corporate Finance, Vol. 42, pp. 100-114. 
[32] Lin, C., Officer, M. S., Wang, R. and Zou, H. (2013). Directors' and officers' liability insurance and loan spreads, Journal of Financial Economics, Vol. 110 No.1, pp. 37-60.

[33] Liu, Y., Ning, Y. and Davidson, W. N. Sr. (2010). Earnings management Surrounding new debt issues The Financial Review, Vol.45 No.3, pp. 659-681.

[34] Ni, Y. S. and Chen, K. Y. (2005). The relationship between cost of debt and financial statements-an example of listing stocks of the traditional industry in TSE, Journal of Business Administration, Vol.64, pp.53-78.

[35] Park C. (2000). Monitoring and structure of debt contracts. The Journal of Financial, Vol.55 No.5, pp. 2157-2195.

[36] Peasnell, K.V., Pope, P. F. and Young S. (2005). Board monitoring and earnings management: Do outside directors influence abnormal accruals? , Journal of Business Finance, Vol.32 No 7-8, pp. 1311-1346.

[37] Roychowdhury, S. (2006). Earnings management through real activities manipulation, Journal of Accounting and Economics, Vol.42 No3, pp.335-370.

[38] Schipper, K. (1989). Commentary on earnings management, Accounting Horizons, Vol.3 No 4, pp. 91-102.

[39] Sengupta, S. (1998). Corporate disclosure quality and the cost of debt, The Accounting Review, Vol.73 No 4, pp. 459-474.

[40] Shailer, G. and Wang, K. (2015). Government ownership and the cost of debt for Chinese listed corporations, Emerging Markets Review, Vol. 22, pp.1-17.

[41] Tang, L. F., Lia, H. M. and Li, J. Z. (2014). The effect of directors and officers liability insurance on earnings management behavior of managers, Academia Economic Papers, Vol. 42 No.3, pp. 331-368.

[42] Trueman, B. and Titman, S. (1988). An explanation for accounting income smoothing, Journal of Accounting Research, Vol. 26, pp. 127-139.

[43] Tsai, C. C., Liu, J. L., Liu, Y. C. and Hao, C. W. (2017). Directors' and officers' liability insurance and the cost of debt, Journal of Economics, Business and Management, Vol. 5 No.7, pp. 266-271.

[44] Tsao, S.M., Lin, C.H. and Chen, V.Y. (2015). Family ownership as a moderator between R\&D investments and CEO compensation, Journal of Business Research, Vol. 68 No.3, pp. 599-606.

[45] Watts, R. L. and Zimmerman, J. L. (1990). Positive accounting theory: A ten year perspective, The Accounting Review, Vol.65 No.1,pp.131-156.

[46] Wynn, P.J. (2008). Legal liability coverage and voluntary disclosure, The Accounting Review, Vol. 83, pp.1639-1669.

[47] Yang, I. H., Tsai, C. C., Chuang, F. H. and Chang, Y. L. (2016). Impact of directors' and officers' liability insurance and family firms on real earnings management, Taiwan Business Performance Journal, Vol. 9 No.2, pp. 107-136.

[48] Yuan, R., Sun, J., and Cao, F. (2016). Directors' and officers' liability insurance and stock price crash risk, Journal of Corporate Finance, Vol.37, pp.173-192.

[49] Zhao, Y. J., Chen, K. H., Zhang, Y. Q. and Davis, M. (2012). Takeover protection and managerial myopia: Evidence from real earnings management, Journal of Accounting and Public Policy, Vol. 31 No.1, pp. 109-135. 